\title{
JPSE
}

(Journal of Physical Science and Engineering)

Received
08 May 2021
Revised
19 June 2021
Accepted for Publication
29 June 2021
Published
01 October 2021

\section{Trial of DC Submersible Pump 12 Volt 50 Watt with Solar Power and Relationship between Water Discharge and Storage Height}

\author{
A Swandi ${ }^{1 *}$, S Rahmadhanningsih ${ }^{2}, S$ Viridi $^{3}$, and I M Sutjahja ${ }^{3}$ \\ 1. Program Study of Physics Education, Faculty of Teacher Training and Education, Universitas \\ Bosowa, Jl. Urip Sumoharjo 4, Makassar, 90231, Indonesia. \\ 2. Postgraduate Program, Faculty of Mathematics and Natural Sciences, Institut Teknologi \\ Bandung, Jl. Ganesha 10, Bandung, 40132, Indonesia. \\ 3. Department of Physics, Faculty of Mathematics and Natural Sciences, Institut Teknologi \\ Bandung, Jl. Ganesha 10, Bandung, 40132, Indonesia.
}

*E-mail: ahmad.swandi@universitasbosowa.ac.id

\begin{abstract}
One of the biggest problems for farmers in the dry season is the lack of water supply for irrigation. Currently, various types of pumps have been widely used, such as fuel pumps and pumps with PLN electricity. However, the costs required to operate these tools are pretty expensive. The solution to overcome this is using DC submersible pumps using solar panels as an energy source. The purposes of this study are to (1) determine the duration of operation of the DC submersible pump with the specifications of the battery and solar panels used, and (2) determine the productivity of the DC submersible pump in terms of the resulting discharge for various storage height conditions used. The research method used is an experimental research method using a quantitative approach. The results of this study are (1) DC submersible pump can operate for 240 minutes with 20 Ah battery at maximum voltage and uses $60 \mathrm{Wp}$ solar panels, and (2) the height of the storage has an effect on the resulting discharge, there is a reduction in the resulting discharge every 0.5 meters increase in the height of the storage. Based on the analysis results, the maximum height limit for submersible pump push is 3.7 meters using a $3 / 4$ inch hose. The results of this study can be a reference for farmers or users to determine the height of the water storage.

Keywords: Submersible DC electric pump, water discharge.
\end{abstract}

\section{Introduction}

The availability of water for irrigation of secondary crops in the dry season needs to be considered because plants' productivity, especially palawija, is primarily determined by the availability of water for irrigation [1], [2]. Plants that do not get adequate irrigation will die and result in crop failure, so that the losses experienced by farmers are enormous. The traditional irrigation system transporting water by human labour is very ineffective because, apart from requiring a large amount of energy, often watering plants on a large scale is not optimal [3]-[5].

One of the activities carried out by farmers to overcome water availability is by using gasoline and diesel fuel pumps [6], [7]. This activity is very ineffective and causes more significant losses to farmers. The operation of the fuel pump is very wasteful. Besides, it requires much energy to move the pump from home to the field. Apart from using the fuel pump, some farmers also use the PLN electric pump. However, this is a particular problem for some farmers whose gardens or rice fields are pretty far from the PLN electricity source. In addition, the energy by the pump is quite large. The energy, which should be used to power other electronic components, must transfer to the operation of the PLN electric pump [3], [5].

Innovation in the use of electric pumps that are energy efficient and can be easily moved from one place to another is needed to overcome the problems that have been described before [8]-[10]. One type of pump that can be used is a 12 volt DC submersible electric pump [9], [11], [12]. This type of pump is a pump that is dipped directly into the water by requiring a DC power source from the battery [13]-[15]. This is considered very effective because the pump's size and battery required are relatively 
small and can be moved easily. Besides that, equipment installation can also be done quickly and more safely. This pump will be more efficient and used for a long time if the battery used can be recharged [16]-[18]. If the pump is used frequently, an electric pump with a battery and solar panels can be installed [19]. Several previous studies on the use of submersible pumps only focused on designing and testing the pump's ability when connected to solar panels [11], [20]. In addition, another study conducted a test of the water discharge generated by the pump at the height of four meters. This study does not present the maximum height that can be reached by the submersible pump used [21]. In addition, several studies on the use of pumps with solar panels use AC-type pumps so that an inverter is needed to convert DC electricity to AC. Indeed, many DC pumps powered by 12 volt batteries have been manufactured. The flow of electricity from the battery to the pump is more stable with a DC pump than with an AC pump that uses an inverter, so the flow of electricity from the battery through the inverter is often unstable, affecting the pump's resistance [22].

A DC submersible pump is a pump that can be completely submerged in water using DC electricity. The motor is tightly sealed and securely attached to the pump body. A submersible pump pushes water to the surface by converting rotational energy into kinetic energy. This is done by water being drawn into the pump and then by rotating the impeller pushing the water through the diffuser to rise to the surface. The main advantage of a submersible pump is that it does not need to be primed because it is already submerged in the liquid. Submersible pumps are also very efficient because they do not have to spend much energy to move water into the pump. The water pressure pushes water into the submersible pump, thus "saving" a lot of pump energy. Moreover, the submersible pump is quiet because it is underwater, and cavitation is never a problem, as there is no pressure "spike" as water flows through the pump. By submerging the entire pump body into the water, the submersible pump can work much longer than other types of pumps.

However, what is the capability of a DC submersible electric pump? Is it able to push water into storage that is placed at a certain height? The answers to these questions are critical because if the storage height from the pump position is too great, the DC submersible pump will be unable to push water into the storage. Conversely, if the height of the storage is shallow, the hydrostatic pressure of the water in the storage is minimal, so that it is unable to push the water further, so irrigation with a long hose cannot be done. In addition, analysis of pump, storage, and battery specifications is critical to determine whether watering a particular plant can be done optimally. For example, rice plants that require more maximum irrigation than chilli plants certainly require a larger battery size and storage.

Therefore, it is necessary to test the DC submersible pump first. The formulation of the problem to be answered in this study is how the effectiveness of the DC electric submersible pump used is seen from two indicators, namely (1) how long the DC submersible pump can operate using a specific size solar panel and battery, and (2) how the water flow changes generated by a DC submersible pump due to changes in storage height.

\section{Method}

This research is preliminary research before direct application in society. This research design uses an experimental research method with a quantitative approach. This research is divided into two activities, namely (1) determining how long a 12 volt 50 watts DC submersible pump can operate using $60 \mathrm{Wp}$ solar panels and $20 \mathrm{Ah}$ batteries, and (2) calculate the water discharge produced by DC submersible pumps at various storage heights.

The equipment used in this study were (1) measuring tub (gallon) as storage which was used to determine the water discharge with a volume of 19 litres, (2) a stopwatch to measure the operating time of the DC pump, (3) a meter to measure the height of the storage, (4) 12 volt 20 Ah battery as the primary source, (5) cables as a liaison between electronic components, (6) a hose with a diameter of $3 / 4$ inch for draining water from the water source to the storage, and (7) $60 \mathrm{Wp}$ solar panel which functions to charge the battery. A view of the solar panels and a schematic of the research carried out are shown in Figure 1. 


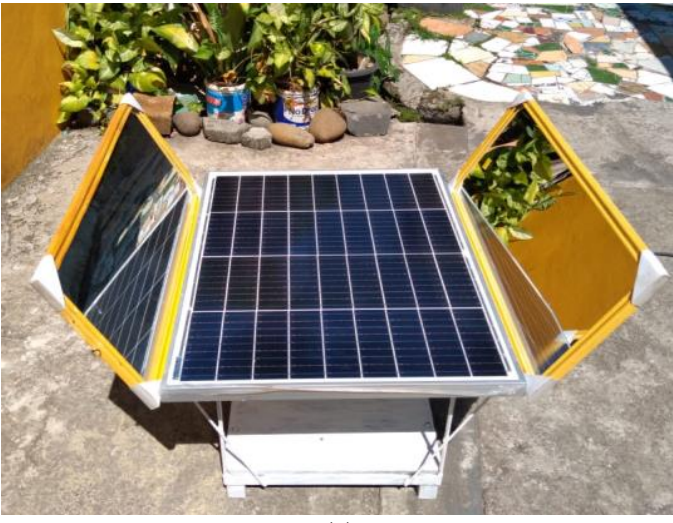

(a)

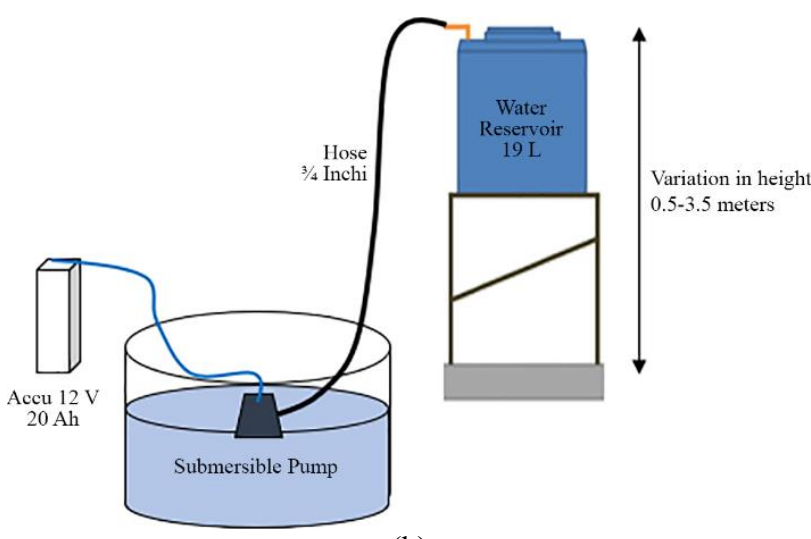

(b)

Figure 1. (a) $60 \mathrm{Wp}$ solar panels and their components; (b)Arrangement of experimental instruments.

In this study, there are two primary sources. Primary data is obtained by operating a DC pump connected to a battery and solar panels. The pump placed in the basin will drain the water using a 5 meters long hose. The end of the hose is then placed back into the basin so that the water circulates. The data collection process can be seen in https://youtu.be/7w2pRxuzTQI. Primary data collection is also carried out by flowing water from the water source to the gallon (storage) for variations in height and is carried out seven times. Initially, the researchers wanted to take data up to a height of 5 meters according to the DC pump specifications. However, equipment limitations so that the maximum height that can be done is 3.5 meters. The volume of gallons used is 19 litres. The discharge can then be determined after obtaining the gallon filling time to the full. This discharge can also be estimated how long it will take to fill the storage commonly used by farmers. In addition, the data obtained can be used to analyze the capacity of batteries and solar panels used for application in the community. The results of this research data collection were then analyzed the data and then presented in a graph.

\section{Result and Discussion}

In the first activity, data collection was carried out from 10.00 volts, with the output voltage produced by the solar panel was 20.98 volts. While the power and current entering the battery are 4.6 watts and $0.37 \mathrm{~A}$, respectively. The battery voltage before data collection is 12.7 volts. As shown in Figure 2, battery voltage data retrieval is performed every 20 minutes to obtain data on changes in battery voltage.

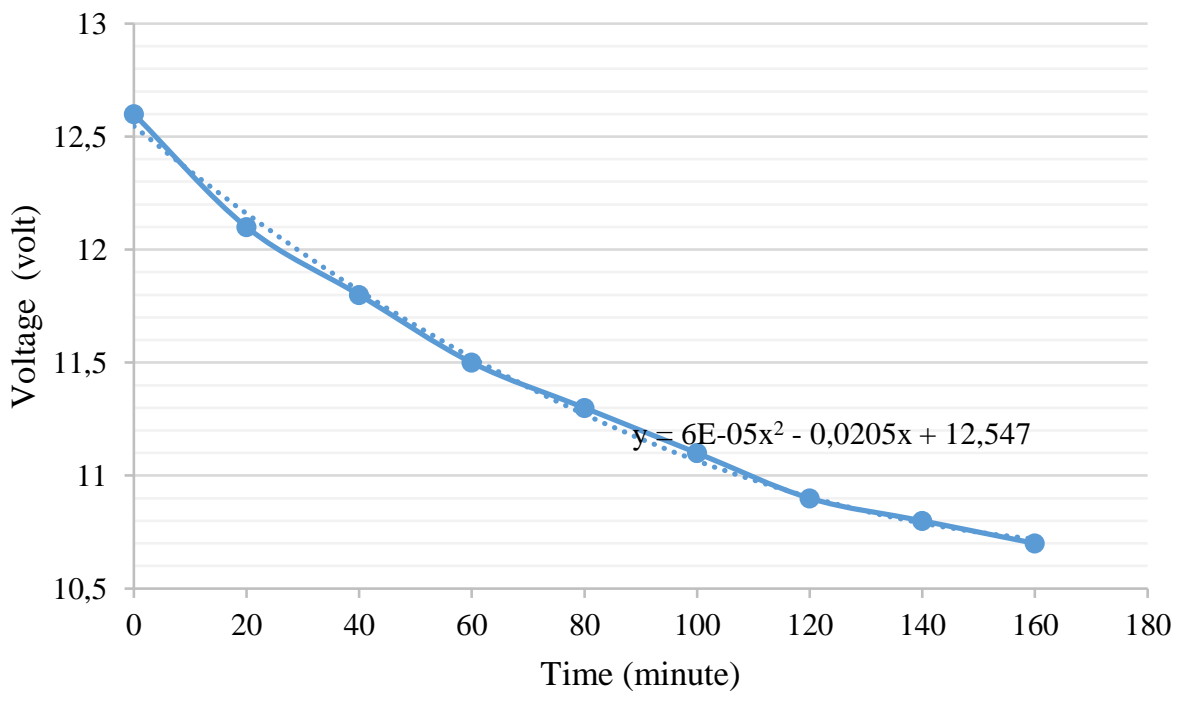

Figure 2. Relationship between battery voltage and time. 
The selection of the type of trendline is based on the suitability of the research data curve. The polynomial trendline is closer to the data curve than if using other trendlines. With the equation of the relationship between the two variables on the graph, we can predict the battery voltage at any time. From the graph above, it can be seen that for 2 hours 40 minutes. There was a decrease in battery voltage. In other words, within 160 minutes, the battery voltage is reduced by 2 volts until it reaches a minimum voltage of 10.7 volts. Compared with theoretical calculations, the duration of operation of a 50 watts DC submersible pump uses a 20 Ah battery, assuming a maximum voltage of 14.4 volts and a minimum voltage of 10.7 volts is 228 minutes. The difference in time duration is because the battery used is not at the maximum voltage. Therefore, it is necessary to collect data by first making sure the battery is at maximum voltage. However, with the trendline polynomial equation on the graph, it can be predicted that the operating time of the DC pump at the maximum voltage to the minimum battery voltage is \pm 240 minutes. So, it can be concluded that the use of solar panels increases the duration of operation of the DC pump by 12 minutes.

Further research should be carried out using batteries with the exact specifications and with maximum initial voltage. It aims to strengthen conclusions about the effect of using solar panels. In addition, data collection was also carried out two times, namely without solar panels and with solar panels. So, with the specifications and initial conditions of the battery and other variables made the same, it can be clearly concluded the role of solar panels.

After the equipment is arranged, as shown in Figure 1b, data were collected by the team. The primary data obtained is the time to fill gallons. Then the time in "seconds" is converted to units of "hours" to obtain the resulting water discharge. The following are the test results of a DC submersible electric pump for height variations.

Table 1 shows that data was collected seven times by increasing the height by 0.5 meters each time. The time to fill a gallon with a volume of 19 litres is measured using a stopwatch. Time in seconds is then converted into hours. So that with the discharge equation, the water discharge from the submersible pump is obtained in units of litres/hour. Table 1 also shows a decrease in water discharge as the height of the gallons increases. Graph analysis with Excel is used to see and determine the equation that relates the height of the gallon to the water discharge generated by the pump. The description of the relationship between gallon height $(h)$ and water discharge $(Q)$ is shown in Figure 3.

Table 1. Water discharge according to the storage height (gallons).

\begin{tabular}{cccc}
\hline $\begin{array}{c}\text { Height } \\
\text { (meter) }\end{array}$ & $\begin{array}{c}\text { Time } \\
\text { (second) }\end{array}$ & $\begin{array}{c}\text { Time } \\
\text { (hour) }\end{array}$ & $\begin{array}{c}\text { Discharge } \\
\text { (litre/hour) }\end{array}$ \\
\hline 0.5 & 31 & 0.008611 & $2,206.452$ \\
\hline 1.0 & 35 & 0.009722 & $1,954.286$ \\
\hline 1.5 & 41 & 0.011389 & $1,668.293$ \\
\hline 2.0 & 50 & 0.013889 & $1,368.000$ \\
\hline 2.5 & 65 & 0.018056 & $1,052.308$ \\
\hline 3.0 & 112 & 0.031111 & 610.714 \\
\hline 3.5 & 347 & 0.096389 & 197.118 \\
\hline
\end{tabular}

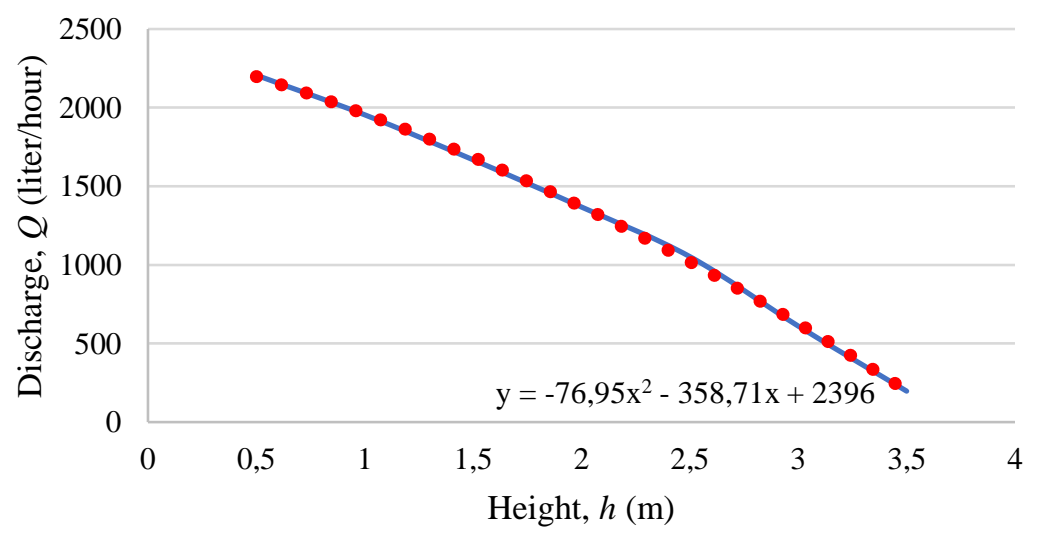

Figure 3. Graph of the relationship between gallon height and discharge. 
Table 2. Charging time and battery specifications according to the storage volume.

\begin{tabular}{|c|c|c|c|}
\hline Volume (litre) & Time (hour) & Type of Accu (V; Ah) & Information \\
\hline \multirow{2}{*}{300} & \multirow{2}{*}{1.52} & $12 \mathrm{~V} 20 \mathrm{Ah}$ & Suitable \\
\hline & & $12 \mathrm{~V} 50 \mathrm{Ah}$ & Suitable \\
\hline \multirow{2}{*}{500} & \multirow{2}{*}{2.54} & $12 \mathrm{~V} 20 \mathrm{Ah}$ & Suitable \\
\hline & & $12 \mathrm{~V} 50 \mathrm{Ah}$ & Suitable \\
\hline \multirow{2}{*}{1,100} & \multirow{2}{*}{5.58} & $12 \mathrm{~V} 20 \mathrm{Ah}$ & Not Suitable \\
\hline & & $12 \mathrm{~V} 50 \mathrm{Ah}$ & Suitable \\
\hline \multirow{2}{*}{2,200} & \multirow{2}{*}{11.16} & $12 \mathrm{~V} 20 \mathrm{Ah}$ & Not Suitable \\
\hline & & $12 \mathrm{~V} 50 \mathrm{Ah}$ & Suitable \\
\hline
\end{tabular}

The water discharge data for various gallon heights are then linked to a graph in Excel. Then a trendline option is carried out to see the pattern/shape of the relationship between the two quantities. The selection of the type of trendline is based on the suitability of the research data curve. Trendline polynomials are closer to the data curve than when using other trendlines. By using a second-order polynomial, an equation that relates the water discharge on the $y$-axis and the height on the $x$-axis is obtained (Equation 1).

$$
Q=-76,95 h^{2}-358,71 h+2396
$$

Where $Q$ is the water discharge produced by the pump and $h$ is the height of the storage. This equation is critical to predicting the maximum storage height. Because the equipment owned can only take measurements at the height of 3.5 meters, measurements at the maximum height based on the guidance (5 meters) cannot be carried out. By using Equation 1, the discharge will approach zero if the hight or $h$ value is 3.71 meters. In other words, the maximum height of the storage that a DC 12 volts submersible pump can reach is 3.71 meters. This is different from the specifications written on the guidance, where the maximum height that can be reached is 5 meters. This may be due to the diameter of the hose used in this study is $3 / 4$ inch. It is possible that if you use a hose with a smaller diameter, it can reach heights of more than 3.71 meters. Further research is needed to draw general conclusions.

In general, farmers use different volumes of water storage tanks for irrigation of secondary crops. We have found various sizes of storage volumes in the market. Assuming the storage height is 3.5 meters, of course, filling the storage requires different times. For large volume storage, the battery capacity needs to be enlarged to fill the water storage until it is full. The type of battery with volume and weight that can still be below everywhere is a battery with a specification of 12 volts $50 \mathrm{Ah}$, which can be used for 9.59 hours. According to the analysis results, the following calculations are the time needed to fill various sizes of storage tanks.

Table 2 demonstrates that the greater the size of the storage volume, the longer it will take to fill the storage is also greater. In fact, the duration of filling can be reduced by reducing the storage height, but the hydrostatic pressure generated by the water will decrease so that water cannot flow very far. This is effectiveless for large plantations.

\section{Conclusion}

Based on the results of data collection and analysis, it can be concluded that (1) the use of $60 \mathrm{Wp}$ solar panels can increase the duration of operation of the 12 volts 50 watts DC Submersible pump for 12 minutes or about $5.2 \%$ of the time duration if solar panels are not used; and (2) there is a decrease in water discharge if the height of the storage which is formulated is increased. The maximum height of the tub that the 12 volts 50 watts DC pump can reach is 3.71 meters when a hose with a diameter of 34 inches is used. This is in contrast to the pump's specification, which states that it can push water up to a height of 5 meters. The hose diameter probably causes this to use a smaller diameter so that the range (speed) of water flow is more significant. To reach a more general conclusion, additional research with high-voltage batteries is required, so that the duration of operation of the DC pump can be calculated directly from the study's findings. Furthermore, data must be collected without using solar panels to compare the data so that the value of the influence of using solar panels can be obtained directly from the data, rather than through predictions based on the equations that appear on the graph. 


\section{References}

[1] M. Yuhendri, A. Aswardi, and A. Ahyanuardi, "Implementasi pompa air tenaga surya menggunakan inverter boost satu fasa," INVOTEK: J. Inov. Vokasional dan Teknol., vol. 20, no. 3, pp. 1-10, 2020, doi: 10.24036/invotek.v20i3.813.

[2] N. Azhar, B. Hussain, M. Y. Ashraf, and K. Y. Abbasi, "Water stress mediated changes in growth, physiology and secondary metabolites of desi ajwain (Trachyspermum ammi L.)," Pak. J. Bot., vol. 43, special issue, pp. 15-19, 2011.

[3] M. Saputra, A. Yusra, and A. Syuhada, "Kajian penggunaan energi surya dan energi bayu sebagai penggerak pompa air-tanah untuk pengairan pertanian," J. Mekanova: Mekanikal, Inov. Teknol., vol. 3, no. 1, pp. 118-127, 2017, doi: 10.35308/jmkn.v3i1.860.

[4] O. A. Saputra and U. Ramelan, "Efektivitas implementasi pompa air tekanan tinggi 12 volt untuk memenuhi kebutuhan air masyarakat, "J. Sainstech, vol. 5, no. 1, pp. 54-59, 2018.

[5] F. Saputra, "Kinerja pompa air DC berdasarkan intensitas tenaga surya," S.T. thesis, Department of Electrical Engineering, Universitas Muhammadiyah Surakarta, Surakarta, Indonesia, 2015.

[6] A. L. Rettob and R. S. Waremra, "Pompa air bertenaga energi matahari (solar cell) untuk pengairan sawah," Musamus J. Sci. Educ., vol. 1, no. 2, pp. 046-052, 2019, doi: 10.35724/mjose.v1i2.1451.

[7] C. Sari, B. Fandidarma, and N. Solikin, "Pompa air harapan: Upaya penanggulangan kekeringan dan pengembangan usaha mandiri masyarakat Desa Kwadungan Lor, Kabupaten Ngawi," Warta Pengabdi., vol. 14, no. 3, pp. 164-172, 2020, doi: 10.19184/wrtp.v14i3.16958.

[8] P. Wulandari and A. Budiman, "Rancang bangun prototipe sistem pompa air mengambang bertenaga surya untuk irigasi tanaman," A.Md.T. thesis, Department of Electrical Engineering, Universitas Muhammadiyah Surakarta, Surakarta, Indonesia, 2017.

[9] P. Widodo and D. A. Nasution, "Rekayasa disain pompa tenaga surya untuk irigasi budidaya bawang merah di lahan kering," in Pros. Sem. Nas. Pengembang. Teknol. Pertani., Politeknik Negeri Lampung, 2016, pp. 292-299, doi: 10.25181/prosemnas.v0i0.492.

[10] M. Taufik, "Prototype pompa air portable tenaga surya," in Pros. Sem. Nas. Sains dan Teknol., Universitas Muhammadiyah Jakarta, 2016, p. TE-019.

[11] B. Setiawan, G. Hidayat, and A. Y. Candra, "Rancang bangun DC submersible pump sistem photovoltaic battery coupled dengan panel surya tipe polycrystalline skala laboratorium," in Pros. Sem. Nas. Sains dan Teknol., Universitas Muhammadiyah Jakarta, 2017, p. TM-019.

[12] M. F. M. Ratu, "Simulasi pengujian karakteristik pompa air menggunakan catu daya modul surya dan baterai siklus dalam," A.Md.T thesis, Department of Electrical Engineering, Politeknik Negeri Kupang, Kupang, Indonesia, 2019.

[13] V. S. Korpale, D. H. Kokate, and S. P. Deshmukh, "Performance assessment of solar agricultural water pumping system," Energy Procedia, vol. 90, pp. 518-524, 2016, doi: 10.1016/j.egypro.2016.11.219.

[14] S. K. Srivastava et al., "Unsustainable groundwater use in punjab agriculture: Insights from cost of cultivation survey," Indian J. Agric. Econ., vol. 70, no. 3, pp. 365-378, 2015.

[15] J. Wang et al., "China's water-energy nexus: Greenhouse-gas emissions from groundwater use for agriculture," Environ. Res. Lett., vol. 7, no. 1, p. 014035, 2012, doi: 10.1088/17489326/7/1/014035.

[16] Usman, A. Sunding, and A. N. Parawangsa, "Analisis kinerja dan ekonomi sistem pompa air tenaga surya skala laboratorium abstrak," J. Teknol. Terap., vol. 4, no. 1, pp. 12-18, 2018, doi: 10.31884/jtt.v4i1.96.

[17] K. L. Yana, K. R. Dantes, and N. A. Wigraha, "Rancang bangun mesin pompa air dengan sistem recharging," J. Pendidik. Tek. Mesin Undiksha, vol. 5, no. 2, p. 10872, 2017, doi: 10.23887/jjtm.v5i2.10872.

[18] M. N. Ibrahim, H. Rezk, M. Al-Dhaifallah, and P. Sergeant, "Solar array fed synchronous reluctance motor driven water pump: An Improved Performance under partial shading conditions," IEEE Access, vol. 7, pp. 77100-77115, 2019, doi: 10.1109/ACCESS.2019.2922358.

[19] C. H. B. Apribowo, T. E. Saraswati, and M. Anwar, "Prototype sistem pompa air tenaga surya untuk meningkatkan produktivitas hasil pertanian," J. Abdimas, vol. 21, no. 2, pp. 97-102, 2017.

[20] S. K. Shanmugam, S. Arumugam, G. Palanirajan, M. Ramachandran, and K. K. Kanagaraj, "Implementation of solar photovoltaic array and battery powered enhanced DC-DC converter 
using B4-inverter fed brushless DC motor drive system for agricultural water pumping applications," J. Vibroeng., vol. 20, no. 2, pp. 1214-1233, 2018, doi: 10.21595/jve.2018.19449.

[21] H. H. Sinaga, D. Permata, N. Soedjarwanto, and N. Purwasih, "Pompa air tenaga surya untuk irigasi persawahan bagi masyarakat Desa Karang Rejo, Pesawaran, Lampung," Wikrama Parahita: J. Pengabdi. Masyarakat, vol. 5, no. 1, pp. 22-26, 2021, doi: 10.30656/jpmwp.v5i1.2633.

[22] F. Alkarrami, T. Iqbal, K. Pope, and R. Rideout, "Dynamic modelling of submersible pump based solar water-pumping system with three-phase induction motor using MATLAB," J. Power and Energy Eng., vol. 08, no. 02, pp. 20-64, 2020, doi: 10.4236/jpee.2020.82002. 